\title{
SCINAIA COMPLANATA (COLLINS) COTTON VAR. INTERMEDIA FROM THE MEDITERRANIAN SEA OF ALEXANDRIA, EGYPT.
}

\author{
Magda A. Shafik \\ Department of Biological and Geological Sciences, Faculty of Education, \\ Alexandria University.
}

\begin{abstract}
Scinaia complanata (Collins) Cotton var. intermedia (Rhodophyta) was newly recollected from Abu-Qir locality along Alexandria seashore. The alga showed multiaxial construction, dichotomously branched thallus, attached to the rocks by multicellular rhizoids. The female gametophyte carried unilocular, uninucleate carpogonia produced on carpogonial branches. Constitutive urea-amidolyase was the enzyme responsible for ${ }^{14} \mathrm{C}$ urea-degradation in this alga; ${ }^{14} \mathrm{C}$-urea transported via passive mechanism. This alga was characterized by its high protein, amino acids, fatty acids, Ash and $\mathrm{Mg}$ contents. It was also characterized by absence of mercury, low $\mathrm{Ni}, \mathrm{Mn}, \mathrm{Zn}$ and Co contents; as well as low iodine value.

Key words: Alexandria, Cell contents, ${ }^{14} \mathrm{C}$-uptake, Mediterranean, Scanning, Scinaia complanata.
\end{abstract}

\section{Introduction}

Until this decade relatively little was known about Scinaia species from Alexandria (Aleem, 1945). The genus Scinaia (Rhodophyta) was firstly detected in Sweden by Agardh (1822). It was classified as a member of family Chaetangiaceae of order Chaetaginales from the Rhodophyceae (Tseng, 1941). This family comprised only one genus; Scinaia. Chaetangiaceae family differed morphologically and anatomically from family Nemalionaceae of order Nemalionales (Feldmann, 1942). In 1989; Wynne classified Scinaia as a member of family Galaxaureaceae of order Nemaliales. Scinaia species were recorded from most of the Mediterranean basin countries: Egypt, France, Spain, Britain, Italy, Portugal, Sweden, Irland, Tunisia, Greece, Dublin, Corsica, Morocco, Turkey, Norway ...etc (Aleem, 1945; Stegenga et al., 1977; Menez and Mathieson, 1981; Wynne, 1989; Silva et al. 1996; Vroom and Abbott, 2004; Brands, 2007).

Recent studies indicated that the genus Scinaia is a world-wide, comprises approximately 49 species, subspecies, varieties, forms, and cultivars in this genus most of the publication were concerned about identification and morphological characters (Huisman, 1985; 1986; 2004; 2006; Wynne, 2005; Guiery and Guiery, 2007). 
Two species from Scinaia were recorded in Alexandria (Aleem, 1945 and 1993):

-Scinaia pseudocrispa (Clemente), 1807 = Scinaia forcellata Bivona-Bernardi in Svedilius 1915.

-Scinaia complanata (Collinis) Cotton var. intermedia. Boergesen, 1916.

Scinaia complanata (Rhodophyta, Florideophycae, Nemaliales, Galaxauraceae) was detected in the Mediterranean for the first time by Agardh (1822). Also, the specimens found in Alexandria washed ashore during August, 1944 for the first time and were fertile (Aleem, 1945). Since that date no detection for this species in other check lists of the marine algal flora of Alexandria (Savigny and Audowin, 1809; Delile, 1813; Areschoug, 1870; Muschler, 1908; Nasr, 1940 a and b; Khalil, 1987 and Aleem, 1993).The present specimens were obtained from Mandra, near Abu Qir, from the depth $2 \mathrm{~m}$. It was easily distinguished from $S$. pseudocrispa by its polygonal epidermal cells and its ovoid cystocarps.

The aim of this study is to shed a light on this unknown species from physiological and morphological point of view.

\section{Materials and Methods}

Abu-Qir locality is an estuary, located at the east of Alexandria (northeastern the Mediterranean basin) between longitudes $30^{\circ} 5^{\prime}$ and $30^{\circ} 22^{\prime} \mathrm{E}$ and latitudes $31^{\circ} 16^{\prime}$ and $31^{\circ} 28^{\prime}$, with average depth of $12 \mathrm{~m}$ (Nessim and El-Deek, 1993), with a temperatures minimum of $18^{\circ} \mathrm{C}$ in April and maximum of $32^{\circ} \mathrm{C}$ in July. It is mainly an exposed rocky site at its north-eastern edge but sandy towards the west.

\section{Algal collection and identification}

Scinaia complanata was firstly collected in April 2001, from Abu-Qir locality as drifted specimens; it appeared again on Abu-Qir seashore by the end of March, and during April 2006; washed ashore from deep water. It was fertile, heavily covered with carpogonia.

The systematic revision of $S$. complanata species based on the comparative morphology described by Holmes (1873); Howe (1914); Yoshida (1998); Huisman (2004 and 2006).

\section{Algal culturing and extraction of urea enzyme:}

Ten grams fresh weight was washed thoroughly with sterilized seawater for several times and bacterial detection was carried out as described by Bekheet and Syrett (1977).

The crude enzyme extract was prepared from the algal material by the method described by Thomas and Syrett (1976) using HEPES buffer at pH 7.6. 


\section{Radioactivity measurements:}

Activity measurement was made by the ${ }^{14} \mathrm{CO}_{2}$ technique released after the injection of ${ }^{14} \mathrm{C}$-urea. Radioactivity was measured by Beckman LS200 B Liquid Scintillation Counter as described by Price (1983).

To assess whether the enzyme present was urease or urea- amidolyase, the assay was carried out in presence of ATP $(5 \mu \mathrm{M} / \mathrm{mL})$, avidin $(100 \mu \mathrm{g} / \mathrm{mL})$, hydroxyurea $(10 \mu \mathrm{M} / \mathrm{mL})$ biotin $(100 \mu \mathrm{g} / \mathrm{mL})$ and dithiothreitol $(1 \mathrm{mM})$ (Bekheet and Syrett 1977).

\section{Separation and determination of free amino acids}

The ethanol-soluble fractions of the algal suspension were passed through a column of Amberlite 1R-120 $\left(\mathrm{H}^{+}\right)$. Free amino acids were then eluted with $1 \mathrm{~N} \mathrm{NH} \mathrm{NH}_{4} \mathrm{OH}$; homogenized and centrifuged. The supernatant was evaporated under vacuum. The dry residue was dissolved in $0.2 \mathrm{M}$ lithium citrate buffer, $\mathrm{pH}$ 2.2 (Benson et al., 1969), saved for analysis with the amino acid analyzer.

\section{Preparation of Protein-hydrolytes}

For estimation of protein amino acids, the method described by Tempst and Jozef (1983) was used. Calculations were made using the equation given by El-Mahdy and El-Sebaiy (1985).

\section{Fatty acids extraction and identification}

Total lipids were extracted according to Blight and Dyer (1959) by extracting the algal cells with chloroform - methanol (2:1). The total lipids were then converted into fatty acids methyl esters using the procedure described by Radwan (1978). The fatty acids methyl esters were identified as fatty acids using Gas Chromatography, model $4 \mathrm{~cm}$ - Schimadzu equipped with a flame ionized detector. Identification of individual fatty acid was carried out by comparing its retention time with those of standards.

\section{Iodine value}

Iodine number of lipids was determined by using the method described by Yasuda (1931): I.N. $=\mathrm{a}-\mathrm{b} / \mathrm{c} \times 1.27 / 5$

Where $\mathrm{a}=$ volume for blank titration.

$\mathrm{b}=$ volume for $0.02 \mathrm{~N} \mathrm{Na}_{2} \mathrm{SO}_{2} \mathrm{O}_{3}$ titration.

$\mathrm{c}=$ weight of lipid in $\mathrm{g}$.

\section{Biochemical analysis}

Protein was measured according to the method of Hartree (1972). The phenol - sulphoric method (Dubois et al., 1959) was applied for carbohydrates estimation, using glucose as a standard. Trace metals contents were carried out as described by Harold et al. (1981). 


\section{Electron micrograph:}

For scanning electron microscopy (SEM), 2-5 samples per specimens were washed in water, air-dried, investigated by the stereomicroscope, mounted on brass stubs and coated with a thin layer of gold using JEOL - JFCL 1100 E ion sputtering. Coated samples were examined and photographed on a JEOL-JSM 5300 SEM with an accelerating voltage of $15 \mathrm{Kv}$ at the Electron Microscopic Unit, Faculty of Science, Alexandria University (Barthlott, 1981).

\section{Results and Discussion}

Scinaia complanata (plate 1) showed erect, cylindrical multiaxial, glittering dense tufts; brownish-red in color. The thallus is dichotomously branched, arise from multicellular rhizoids, branching up to 7 times. The thallus is $9 \mathrm{~cm}$ long and about 1-2 mm thick. Branches are 3-6 mm long. Female gametophyte showed dense growth of carpogonia, no detection for male plant.

On using scanning electron microscope (SEM), multiaxial construction was obtained (Plate 2a). The carpogonia were produced on a segmented carpogonial branches. These branches showed wrapped-edge, inside which the carpogonia were born on long stalks (Plate 2b). Transection of cell surfaces showed soft texture with mall wax depositions (Plate 3a), the enlarged section showed wrinkled surfaces characteristics to these alga (Plate $2 b$ ).

In Plate 4, the carpogonial branches carried numerous carpogonia, produced on each branch (a). Longitudinal sections showed flower-like hair protecting the carpogonium (b). These carpogonia were unilocular, uninucleate structure with single ovum surrounded by very thick wall (Plate $5 \mathrm{a}$ and b). Most of these characters agree with that described by Vroom and Abbott (2004) and Huisman (2006) for the genus Scinaia.

Moisture content of Scinaia complanata was similar to other red algae (Table 1). Ash contents was higher than the corresponding values of Palmaria sp., Porphyra sp. and Porphyra yezoensis, 40.2 compared to 15-30, 8-16 and 7-8, respectively. Protein was also higher than the first alga but less than Porphyra yezoensis and Porphyra sp. (Table 1). Carbohydrates concentration was low compared to the other three algae, it was amounted to 1/4 of that of Porphyra sp. and 1/5 Porphyra yezoensis. Total fat contents were high compared to other red algae (Arasaki and Arasaki, 1983).

Table 2 showed the metal contents of Scinaia complanata compared to other red algae used as food adjuvant for their high nutritive value (Harold et al., 1981). Metal analysis of Scinaia complanata showed high Mn, Cd and Cr; low iron contents while arsenic showed normal concentration. 


\section{Plate 1}
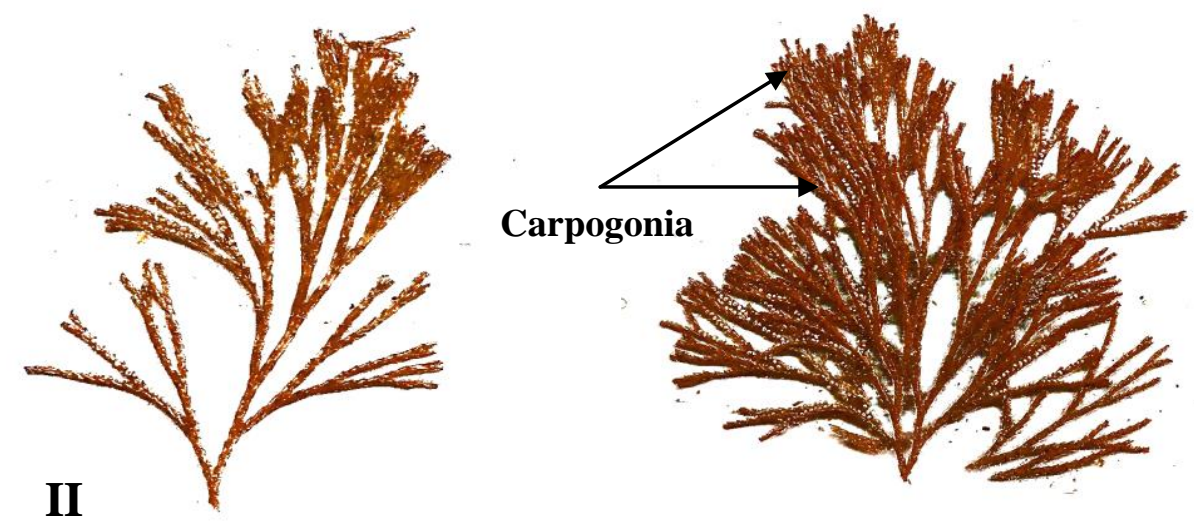

\section{III}

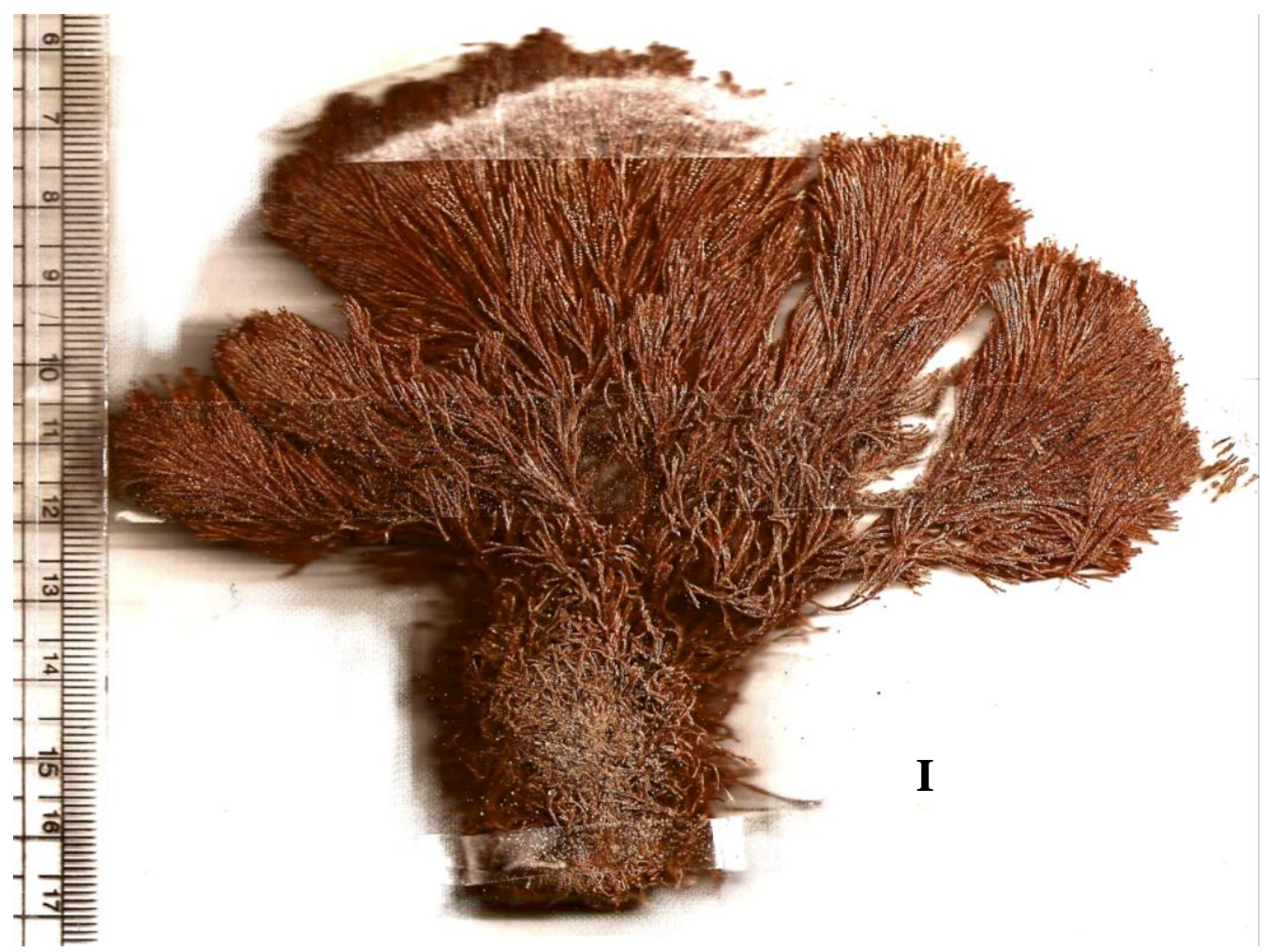

Morphology of Scinaia complanata. I) habit of gametophytic plant; II) mode of branching; III) heavily covered thallus with carpogonia 
Plate 2

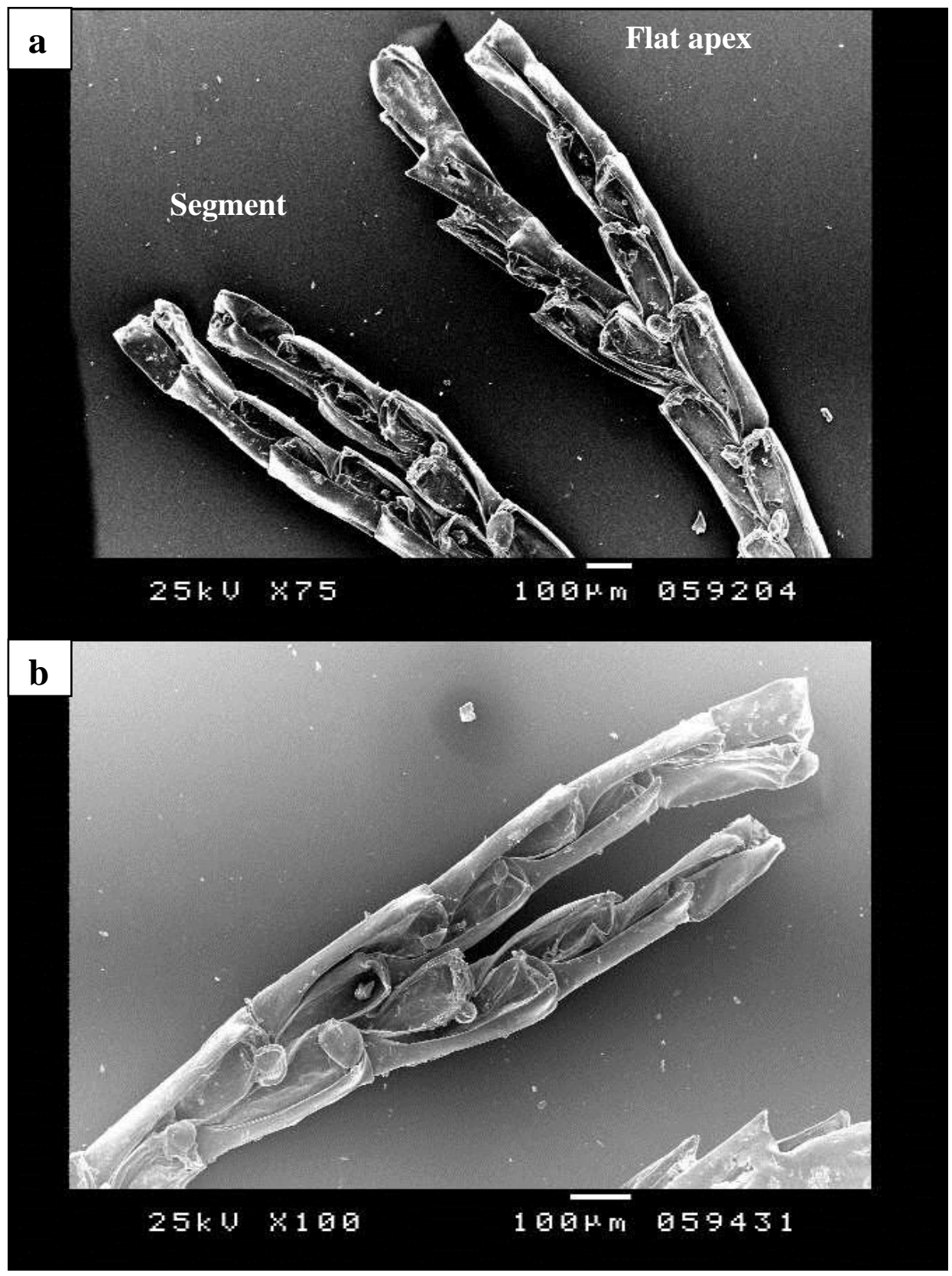

Scanning electron micrograph (SEM) of Scinaia complanata a) dichotomously - branched thallus;

b) wrapped - edged segmented thallus with carpogonia 


\section{Plate 3}

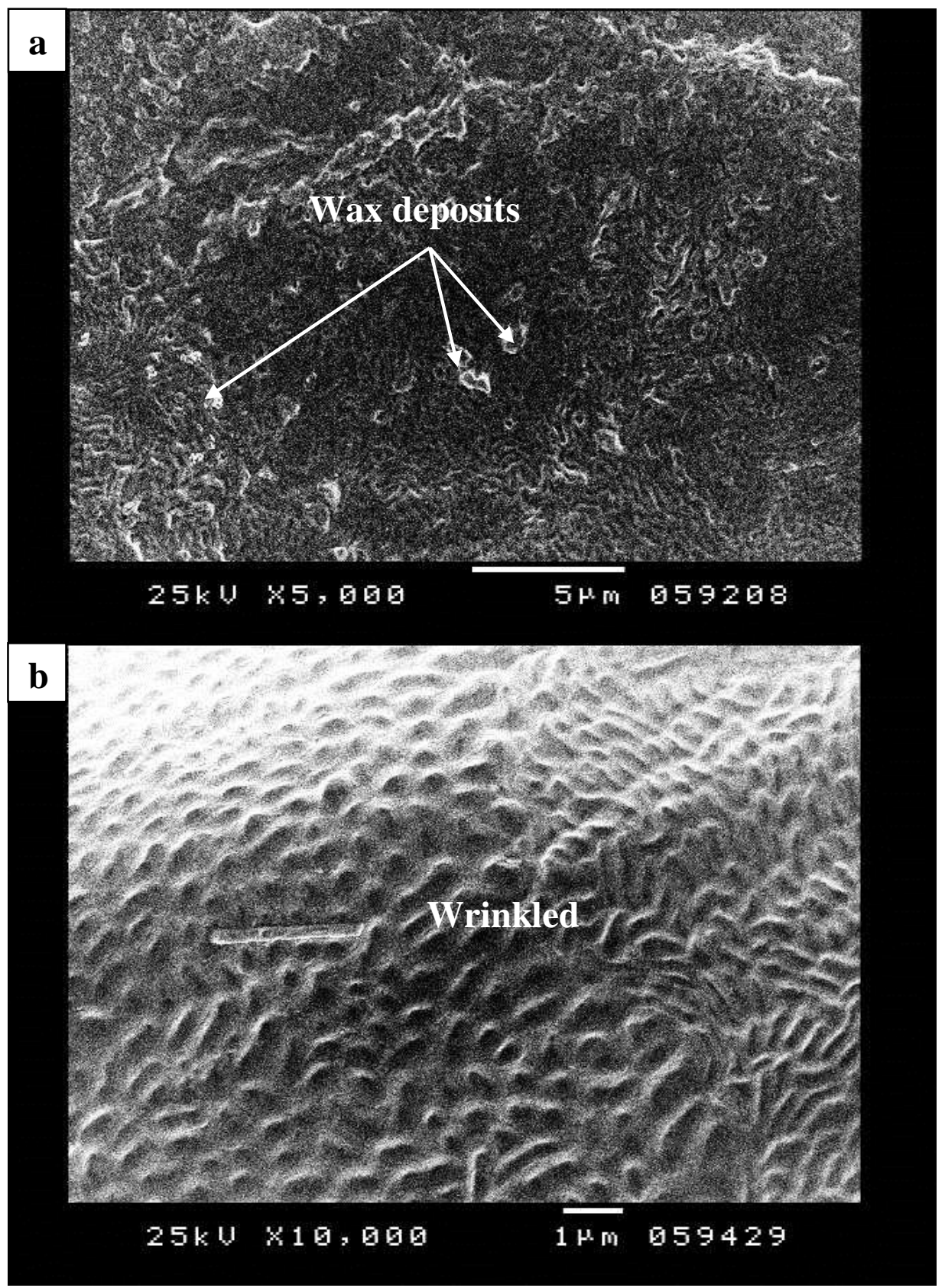

Scanning electron micrograph (SEM) of Scinaia complanata. a) wax deposition b) wrinkled cell surface. 
Magda A. Shafik

\section{Plate 4}

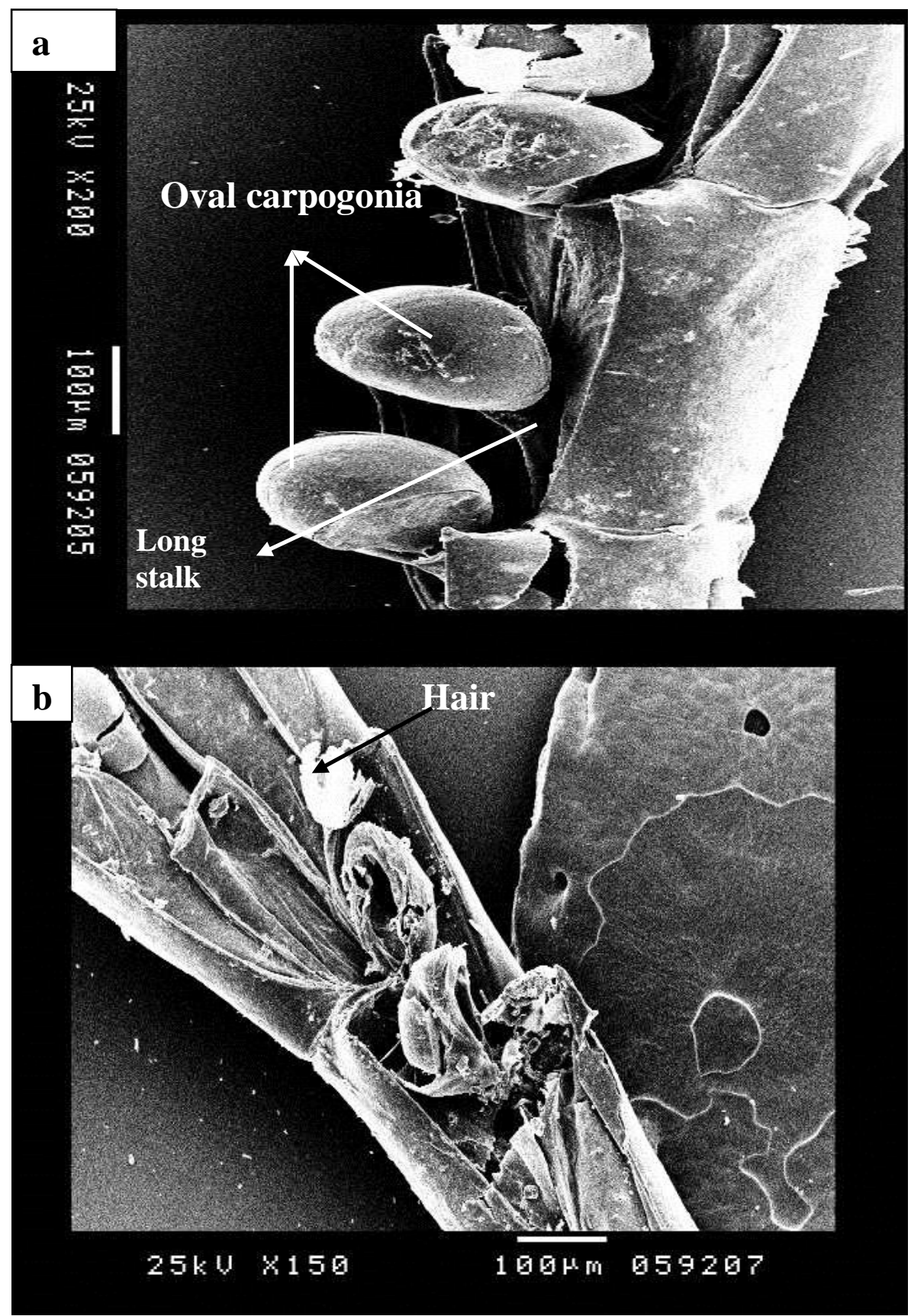

Scanning electron micrograph (SEM) of Scinaia complanata a) carpogonial branch with flower - like hair, b) closed carpogonom 


\section{Plate 5}

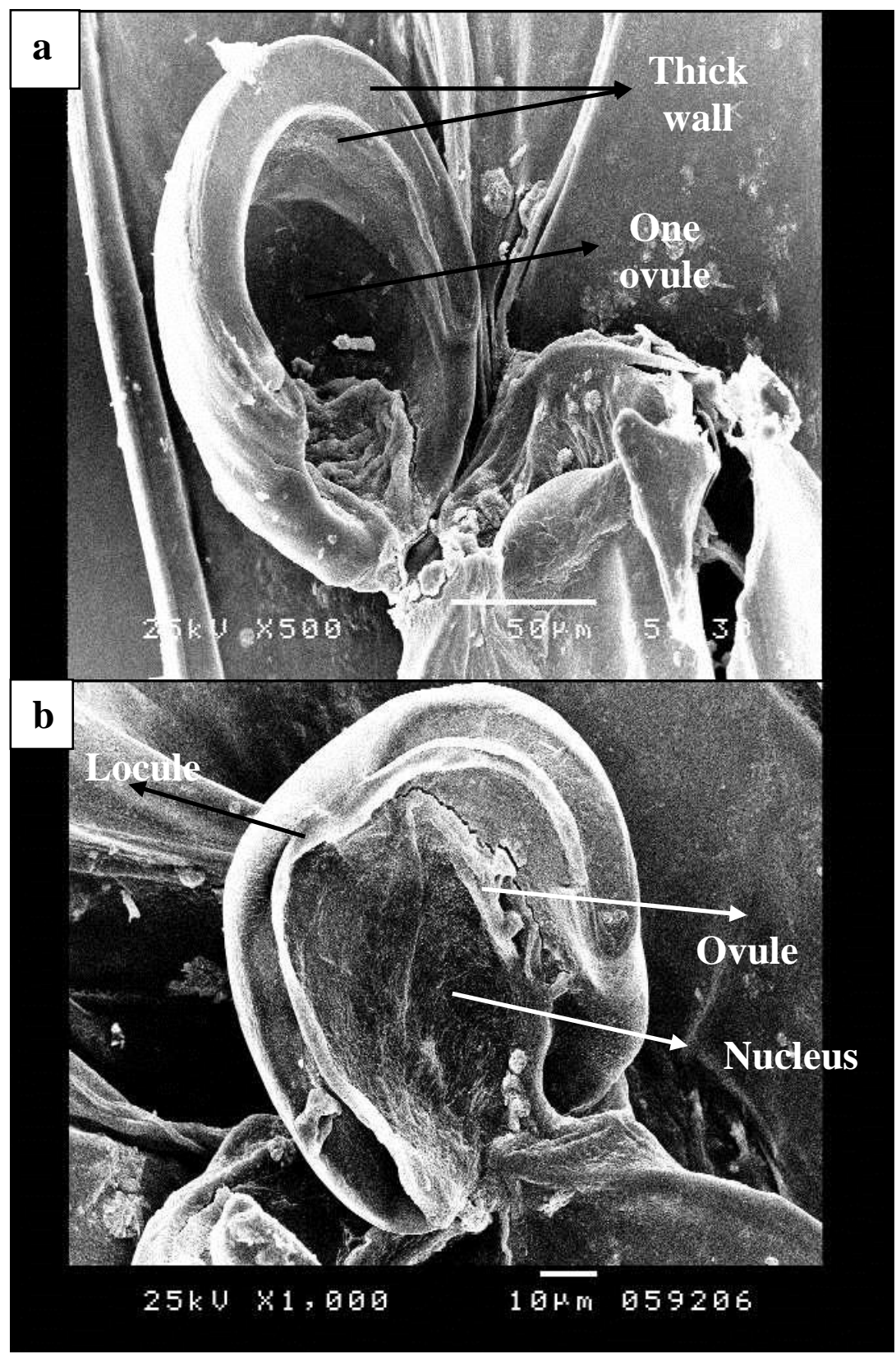

Scanning electron micrograph (SEM) of Scinaia complanata

a) longitudinal section showing thick - walled unilocular carpogonium arise from the segment, b) carpogonium with uninucleate ovum. 
Table (1): Cell constituents of Scinaia complanata compared to some other red algae. Values are g/100g dry wt.

\begin{tabular}{|c|c|c|c|c|c|c|}
\hline $\begin{array}{c}\text { Algal } \\
\text { Species }\end{array}$ & Water & Ash & Carbohydrates & Protein & $\begin{array}{c}\text { Fats } \\
\text { (total) }\end{array}$ & References \\
\hline $\begin{array}{c}\text { Scinaia } \\
\text { complanata }\end{array}$ & 87.50 & 40.2 & 9.55 & 31.0 & 10.5 & - \\
\hline $\begin{array}{c}\text { Palmaria } \\
\text { polmater }\end{array}$ & $79-88$ & $\begin{array}{c}15- \\
30\end{array}$ & N.D. & $8-25$ & $7-9$ & $\begin{array}{c}\text { Morgan } \text { et } \\
\text { al. (1980) }\end{array}$ \\
\hline $\begin{array}{c}\text { Porphyra } \\
\text { sp. }\end{array}$ & 86.00 & $8-16$ & 40.0 & $33-47$ & 3.3 & $\begin{array}{c}\text { Arasaki } \\
\text { and Arasak } \\
(1983)\end{array}$ \\
\hline $\begin{array}{c}\text { Porphyra } \\
\text { yezoensis }\end{array}$ & N.D. & $7-8$ & 49.4 & 43.6 & 2.4 & $\begin{array}{c}\text { Nisizawa } \\
\text { et al. } \\
(1987)\end{array}$ \\
\hline
\end{tabular}

Mercury was completely absent; nickel and manganese comprised about $5 \%$ of the total metal content. Also, zinc and cobalt were present with equal concentrations.

Table (2): Metal contents of Scinaia complanata from the Mediterranean sea of Alexandria, Egypt. Values are $\mu g . g^{-1}$ dry wt \% dry wt.

\begin{tabular}{|c|c|c|}
\hline \multirow{2}{*}{ Metals } & \multicolumn{2}{|c|}{ Scinaia complanata } \\
\cline { 2 - 3 } $\mathbf{F e}$ & $\boldsymbol{\mu g} \cdot \mathbf{g}^{-\mathbf{1}} \mathbf{d r y} \mathbf{~ w t}$ & \% from dry $\mathbf{~ w t}$ \\
\hline $\mathbf{N i}$ & 739.23 & 0.074 \\
\hline $\mathbf{Z n}$ & 21.63 & 0.0021 \\
\hline $\mathbf{C d}$ & 39.72 & 0.0039 \\
\hline $\mathbf{C u}$ & 5.01 & 0.005 \\
\hline $\mathbf{C r}$ & 57.25 & 0.0057 \\
\hline $\mathbf{C o}$ & 3.63 & 0.0003 \\
\hline $\mathbf{P b}$ & 17.26 & 0.017 \\
\hline $\mathbf{M n}$ & 79.06 & 0.0079 \\
\hline $\mathbf{M g}$ & 69.42 & 0.0069 \\
\hline $\mathbf{H g}$ & 29663.7 & 2.9 \\
\hline $\mathbf{A s}$ & -- & -- \\
\hline
\end{tabular}

The data in Table 3 indicated that the enzyme responsible for ureadegradation in Scinaia complanata from the Mediterranean Sea of Alexandria was urea-amidolyase, since no inhibition occurred in presence of hydroxyurea and 
also avidin. Stimulation for cleavage occurred when adding ATP; and inhibition by avidin, it was reversed by prior addition of biotin to the incubation mixture. Urea-amidolyase of Scinaia complanata was a constative enzyme since the uptake mechanism in this alga did not affected by nitrogen starvation (Table 4).

Table (3): Urea degrading enzyme in Scinaia complanata collected from Abu Qir Alexandria. Extraction with HEPES buffer (pH 7.6). Activities as n mol ${ }^{14} \mathrm{CO2}$. protein ${ }^{-1} . h r .{ }^{14} \mathrm{C}$-urea conc. $100 \mathrm{nmol} . \mathrm{mL}^{-1}$.

\begin{tabular}{|c|c|c|c|c|c|}
\hline $\begin{array}{c}\text { Boild } \\
\text { extract }\end{array}$ & -ATP & +ATP & $\begin{array}{c}\text { +ATP } \\
\text { +Avidin }\end{array}$ & $\begin{array}{c}\text { +Avidin } \\
\text { +Biotin }\end{array}$ & $\begin{array}{c}\text { + Hydroxy } \\
\text { urea }\end{array}$ \\
\hline 0.36 & 367 & 824 & 453 & 904 & 821 \\
\hline
\end{tabular}

It should be mentioned that an individual alga may posses one enzyme or the other but not both. Different varieties or strains of the same algal species may show different enzyme activities. It was reported (Syrett and Leftley, 1976) that one difference between the members possessing amidolyase might be that urease is a constitutive enzyme but amidolyase is an inducible one. Bekheet and Syrett (1977) claimed that since there was no known example of an inducible urease in algae. Shafik (1992) proved that Eichhorrnia crassipes plant contained inducible urease. Again, Shafik in 1993 proved that the marine algae Ulva lactuca, Cystoseira larbata, Dictyota dichotoma, Sargassum linifolium, Pterocladia capillaceae and Enteromorpha intestinalis contained inducible urease enzyme.

The rate of appearance of radioactivity in the cell was taken as a measure of the uptake; it was measured by the Scintillation counter (Table 4). The uptake of ${ }^{14} \mathrm{C}$-urea by this alga is a passive mechanism, since the accumulation ratio did not exceeded one, under all time intervals. In the marine algae studied by Shafik (1993), urease enzyme was transported by active mechanism (i.e. accumulation ratios exceeded 1). Williams and Hodson (1977) described two transport systems in Chlamydomonas reinhardii operating in different urea concentration ranges. Also in Saccharomyces, Phaeodactylum and Chlorella two transport systems had been postulated (Shafik, 1993) the first via an active transport system and is sensitive to nitrogen repression, the second passive transport occurs at relatively high external urea concentration.

The amount of amino acids determined by amino acid analyzer was shown in Table 5. Essential and non-essential amino acids were listed, to point out to the nutritive value of this red alga. One of the characteristic features for this alga was its high amino acid contents. 
Table (4): Incorporation of ${ }^{14} \mathrm{C}$-urea into Scinaia complanata marine alga after $10 \mathrm{~h}$ of nitrogen starvation. ${ }^{14} \mathrm{C}$-urea. $100 \mathrm{nmol}_{\mathrm{ml}}{ }^{-1}$. values nmol.ml ${ }^{-1}$. Acc. Ratio= radioactivity in cell / radioactivity in medium.

\begin{tabular}{|c|c|c|c|c|c|c|c|c|}
\hline \multirow[b]{2}{*}{$\begin{array}{c}\text { Time of } \\
\text { incubation }\end{array}$} & \multicolumn{2}{|c|}{$1 \mathrm{~min}$} & \multicolumn{2}{|c|}{$5 \mathrm{~min}$} & \multicolumn{2}{|c|}{10 min } & \multicolumn{2}{|c|}{30 min } \\
\hline & 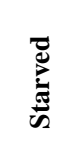 & 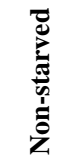 & $\sum_{\frac{\pi}{5}}^{D}$ & 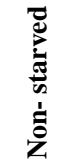 & $\underset{\frac{\pi}{2}}{\stackrel{D}{0}}$ & 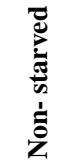 & 苟 & 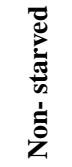 \\
\hline${ }^{14} \mathrm{C}$ in cells & 51.00 & 53.0 & 64.0 & 62.0 & 87.0 & 83.0 & 98.0 & 99.0 \\
\hline${ }^{14} \mathrm{C}$ in medium & 60.70 & 64.60 & 68.10 & 68.13 & 87.88 & 92.20 & 89.09 & 100.0 \\
\hline $\begin{array}{c}\text { Accumulation } \\
\text { ratio } \mathrm{C} / \mathrm{M}\end{array}$ & 0.84 & 0.82 & 0.94 & 0.91 & 0.99 & 0.90 & 1.10 & 0.99 \\
\hline
\end{tabular}

Total essential amino acids comprised only about $20 \%$ from the total amino acid contents of this alga. Total free amino acids represented $19 \%$ from the total amino acid contents of S. complanata.

Table 5: Amino acid contents of Scinaia complanata from Abu Qir Alexandria. Values are $\mu \mathrm{g}$ a.a. $\mathrm{g}^{-1} \mathrm{dry}$ wt and as \% of total protein amino acids.

\begin{tabular}{|c|c|c|c|c|}
\hline \multicolumn{2}{|r|}{ Amino acids } & Protein & Free & $\begin{array}{l}\text { Protein } \% \text { from } \\
\text { total protein a. }\end{array}$ \\
\hline \multirow{7}{*}{ 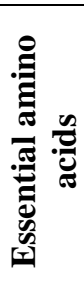 } & Isoleucine & 1.87 & 0.44 & 2.26 \\
\hline & Leucine & 2.89 & 0.68 & 3.49 \\
\hline & Lysine & 2.59 & 0.61 & 3.14 \\
\hline & Methionine & 0.89 & 0.21 & 1.08 \\
\hline & Phenyl alanine & 1.70 & 0.40 & 2.06 \\
\hline & Threonine & 3.61 & 0.85 & 4.36 \\
\hline & Valine & 3.36 & 0.79 & 4.06 \\
\hline \multicolumn{2}{|r|}{ Total } & 16.91 & 3.98 & $20.45 \%$ \\
\hline \multirow{10}{*}{ 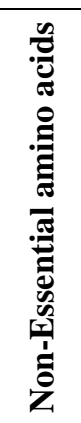 } & Alanine & 7.83 & 1.84 & 9.47 \\
\hline & Arginine & 8.42 & 1.98 & 10.18 \\
\hline & Aspartic & 9.27 & 2.18 & 11.21 \\
\hline & Cystine & 1.36 & 0.32 & 1.64 \\
\hline & Glutamic & 14.13 & 3.32 & 17.07 \\
\hline & Glycine & 12.64 & 2.97 & 15.28 \\
\hline & Histidin & 3.61 & 0.85 & 4.36 \\
\hline & Proline & 5.02 & 1.18 & 6.07 \\
\hline & Tyrosine & -- & -- & -- \\
\hline & Serine & 3.57 & 0.84 & 4.32 \\
\hline \multicolumn{2}{|c|}{ Total } & 65.85 & 15.48 & 79.55 \\
\hline \multicolumn{2}{|c|}{ Total (Es + Non-Es) } & 82.76 & 19.46 & $100 \%$ \\
\hline \multicolumn{2}{|c|}{ Total $(\mathrm{F}+\mathrm{P})$} & \multicolumn{2}{|c|}{102.22} & \\
\hline
\end{tabular}


Total protein hydrolysate amino acids formed about $81 \%$ from the total amino acids determined in this alga. About $65 \%$ from the total non-essential (80\%) were detected in total protein amino acids, the other $15 \%$ were in total free.

Concerning the individual amino acids, some amino acids were present in both the free state and as building stones of proteins. These acids were: glutamic (17\%), glycine (15\%) and aspartic (about 11\%), they form together about half of the protein hydrolysate. Least amounts in both protein and free amino acids were recorded for methionine, cystine, phenyl alanine and isoleucine. Tyrosine was absent from both free and protein amino acids. Proline formed $6 \%$ from the total amino acid contents of this alga.

All the amino acids normally occurring in protein were present also in the free state. The exact balance between amino acids is so dependent on the nutrition prevailing before harvesting the alga. The free amino acid pool in this alga composed of individual amino acids similar to those found in flowering plants (Tempst and Jozef, 1983).

Comparing the results of this investigation with some other red algae (Table 6) indicated that, the amino acids composition of Scinaia sp. coincidence mainly with the other red algae, but the total amino acid content of Scinaia exceeded greatly that of Pterocladia, Chondrus and Microcystis (Table 6). In general, it was observed that Scinaia complanata resembling Chondrus alga in its individual amino acids.

The carbon chain lengths of Scinaia complanata ranged between C6 and C22 (Table 7). Saturated fatty acids comprised 12 fatty acid, while unsaturated comprised only 8 . The most widely distributed fraction among saturated fatty acids were $\mathrm{C} 16$ and $\mathrm{C} 18$. Long chain fatty acids C23 and C24 were absent from the fatty acids of this alga.

The total saturated fatty acids formed about $85 \%$ from the total fatty acid contents in this alga, while unsaturated formed only the other $15 \%$, fractionated into monounsaturated $(9.9 \%)$ and polyunsaturated $(5.1 \%)$. Total unsaturated fatty acids was $3.72 \square$ g.g ${ }^{-1}$ dry wt, monounsaturated fraction represented $66 \%$ of this amount. Only three polyunsaturated fatty acid were detected in this alga. Highest unsaturated acids were C14:1, C15:1 and C20:1.

Fat analysis of Chlorella pyrenoidosa grown on nitrogen-starved media indicated close agreement with the results of this investigation (Schlenk et al., 1960).

Iodine value determines the quality of fats when used as food or food additives, low iodine value indicated high fat quality. The value obtained in this alga was within the normal range (120-200). 
On the light of the above mentioned results, one can conclude that Scinaia complanata resembling typically the vegetative tissue of higher plants (Graeve et al., 2002).

Our knowledge of the marine algal flora of the eastern Mediterranean is still scantly, although the western shores have been fully investigated (Huisman et $a l ., 2005)$. During the study of algal flora on the shores of eastern Mediterranean of Egypt, number of species appeared to be invasive, introduced to the sea through shipping activities or ballast water; others are newly collected. Scinaia complanata was newly collected from Alexandria after 60 years of the first collection. Cystocarpic plants were collected in April 2006 instead of August of 1944 due to the raising in temperature which allowed early reproduction. No indication that invasion occurred to this algal species; the future work will confirm or reject this proposal.

Table 6: Comparison between Scinaia complanata aspects of this investigation and some red and brown algae.

\begin{tabular}{|c|c|c|c|c|}
\hline Alga & Scinaia sp. & Chondrus sp. & Microcystis sp. & Pterocladia sp. \\
\hline Total a.a. & 102.22 & 54.70 & 47.70 & 80.57 \\
\hline $\begin{array}{l}\text { Highest } \\
\text { content }\end{array}$ & glu, gly, asp. & arg, glu, proline, leucine & glu, alanine & hist, arg, isolu, glu \\
\hline $\begin{array}{l}\text { Least } \\
\text { amount }\end{array}$ & meth, cyst, ph.ala, isoleu & meth, ph. ala, cyst, trypt & meth, isoleu & cyst, meth, val. \\
\hline $\begin{array}{l}\text { Absent } \\
\text { a.a. }\end{array}$ & tyrosine & Isoleu, serine & --- & --- \\
\hline $\begin{array}{l}\text { Urea- } \\
\text { enzyme }\end{array}$ & Amidolyase & --- & --- & Urease \\
\hline Category & Inducible & --- & --- & Constitutive \\
\hline $\begin{array}{c}\text { Transport } \\
\text { system }\end{array}$ & Passive & --- & --- & active \\
\hline referance & & Clement et al. (1968) & Fowden (1962) & Shafik (1993) \\
\hline
\end{tabular}


Table 7: Fatty acids contents of Scinaia complanata from Alexandria. Values $\mu \mathrm{g}$ fatty acid.ml ${ }^{-1}$.

\begin{tabular}{|c|c|c|}
\hline \multicolumn{2}{|c|}{ Fatty acids } & $\square \mathrm{g} \cdot \mathrm{mL}^{-1}$ \\
\hline \multirow{12}{*}{ 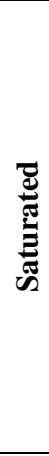 } & C 6:0 & 0.17 \\
\hline & C 8:0 & 0.96 \\
\hline & C 10:0 & 0.07 \\
\hline & C 11:0 & 0.20 \\
\hline & C 12:0 & 0.36 \\
\hline & C 13:0 & 0.28 \\
\hline & C 14:0 & 0.11 \\
\hline & C 15:0 & 0.37 \\
\hline & C 16:0 & 9.31 \\
\hline & C 17:0 & 0.90 \\
\hline & C 18:0 & 5.34 \\
\hline & C 20:0 & 0.20 \\
\hline \multicolumn{2}{|c|}{ Total } & 18.27 \\
\hline \multirow{5}{*}{ 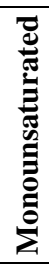 } & C 14:1 & 0.57 \\
\hline & C 15:1 & 0.56 \\
\hline & C 17:1 & 0.24 \\
\hline & C 20:1 & 0.47 \\
\hline & C 22:1 & 0.29 \\
\hline \multicolumn{2}{|c|}{ Total } & 2.13 \\
\hline \multirow{3}{*}{ 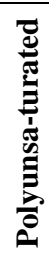 } & C 18:2 & 0.24 \\
\hline & C 22:2 & 0.44 \\
\hline & C 18:3 & 0.42 \\
\hline \multicolumn{2}{|c|}{ Total } & 1.10 \\
\hline \multicolumn{2}{|c|}{ Total (unsaturated) } & 3.23 \\
\hline \multicolumn{2}{|c|}{ Total fatty acids } & 21.50 \\
\hline
\end{tabular}

Iodine value $=\mathbf{1 2 0 . 5 6}$

\section{References}

Agardh, C. (1822). Species Algarum. Vol 1, part 2. Beling, Lund, Sweden, pp. IVIII.

Aleem, A. A. (1945). A contribution to the study of the marine algae of Alexandria and its vicinities. Dissertation submitted for the degree of M.Sc., to Farouk I University, Alexandria, Egypt, 182 pp. 
Aleem, A. A. (1993). Marine Algae of Alexandria Egypt. Egyptian book court. ISBN977-00-528.

Arasaki, S. and Arasaki, T. (1983). Vegetables from the sea. Japan Publ. Inc., Tokyo Japan.

Areschoug, J. (1870). Alger samlade vid Alexandria a framl. Dr. Hedenborg. Oelversjt of Kongi Vertenskaps Akad. For thandlingar. Stockholm. 10: 929939.

Barthlott, W. (1981). Epidermal and seed surface charactyers of plants: systematic applicability and some evolutionary aspects. Nord. J. Bot., 1: 345-355.

Bekheet, I. A. and Syrett, P.J. (1977). Urea-degrading enzymes in algae. Br.Phycol. J., 12: 137-143.

Benson, J. V.; Godon, M.J. and Patterson, J .A. (1969). Accelerated chromalographic analysis of amino acids in physiological fluids containing glutamine and asparagines. Analytical Biochemistry. 18: 228-240.

Bligh, E.G. and Dyer, W.M. (1959). Rapid method for lipid extraction. Can. J. Biochem. Physiol., 35: 911-915.

Boergesen, F. (1916). The marine algae of the Danish West Indies. III, Rhodophyceae (1). Ibid, 3: 1-86.

Brands, S. J. (2007). Systema Nature 2000, the taxonomicon. Universal Taxonomic Services. Amesterdam. The Netherlands. Accessed March. 24: 2007.

Clement G., Rebeller, M. and Trambouze, P. (1968). Utilization massive du gaz carbonique dans la culture d'une nouvelle algae alimentaire. Revue de l'Institute Francais du Petrole et Annals des Combustibles Liquids, Paris, France, 23: 702-711.

Clemente-Rubio, S. (1807). Ensayo sorbre les variedades de la vid comun que vegelan en Andialucia Madrid.

Delile, A. (1813). Florae d'Egypte, Explication de planches. In commission d'Egypte: Description de L'Egypte. Historie Naturelle. 2:49-82.

Dubois, M.; Gilles, K. A.; Hamilton, J.K. and Smith, F. (1959). Phenolsulphoric acid colorimetric method for carbohydrate determination. In: Methods in carbohydrate chemistry. Whist ler, L.R. and Wolform, R.L. (ed.) 388-403. Academic press New York.

El-Mahdy, A. and El-Sebaiy, L. (1985). Proteolytic activity, amino acid composition and protein quality of germinating Fenugreek seeds (Trigonellor foenum graecum L.). Food Chemistry. 18: 19-33. 
Feldmann, J. (1942). Les algues marines de la cote des Aberes. IV Rhodophycees, (P.199-372 extrait de la Rev. Algol. II. 1939:247-330; Ibid. 12:1941:77-100: extrait des Trav. Algol.I, 1942; 29-118.

Fowden, L. (1962). Amino acids and proteins. Physiol. Biochem. Algae, A. Lewin, ed., Academic Press New York, N.Y., USA. 189-206.

Graeve, M., Kaltnes,G., Wiencke, C. and karsten, U (2002). Fatty acid composition of arctic and Antractic macroalgae: indicator of phlogenetic and tropihic relationships. Mar. Ecol. Prog-ser., 231:67-74.

Guiry, M.D. and Guiry, G.M. (2007). Algae Base version 4,2. World-wide electronic publication, Natunal University of Ireland, Galway

Harold, E., Ronald, S. and Ronald, S. (1981). Chemical analysis of food. (eighth edition). Churchill living store. Medical Division of Longman group limited.

Hartree, E.F. (1972). A modification of lawry method that gives a liner photometric response. Anal. Biochem. , 48:422.

Holmes, E.M. (1873). New British algae. Grevillea. 2 London.

Howe, M. (1914). The marine algae of Peru. Memoires of Torrey Botanical Club, 15: 1-185.

Huisman, J. (1985). The Scinaia Assemblage (Galaxauraceae, Rhodophyta): a re-appraisal. Phycologia. 24: 403-418.

Huisman, J. (1986). The red algal genus Scinaia (Nemaliales,Galaxauraceae): from Australia. Phycologia. 26: 167-174.

Huisman, J. (2004). Marine benthic flora of the Dampier Arcchipelago, Western Australia. Records of the Western Australian Museum Supplement. 66:6168.

Huisman, J. M. (2006). Scinaia. In: Algae of Australia Nemaliales (Huisman, J.M. Eds), pp. 93-106. Canberra: Australian Biological Resource Study.

Huisman, J.; Abbott, I and Smith, C. (2005). Hawaiian Reef Plants. University of Hawai Sea Grant, Honolulu

Khalil, A. (1987). A list of the marine algae from Alexandria Coast, Egypt. Bull. Inst. Oceanogr and fish., ARE, 13(1): 229-241.

Menez, E. and Mathieson, A. (1981). The marine algae of Tunisia Smithsonian contributions of the marine Science. No. (10) pp:59. Washington, D.C.

Morgan, K., Wright, J. and Simpson, F. (1980). Review of chemical constituents of red alga Palmaria palmate (dulse). Econ. Bot. 34:27-50.

Muschler, R. (1908). Enumeration des algues marines et d'eau douce observees jusqua ce jour en Egypt. Memoires de l'Institute d'Egypt, tom 5(3): 1-237. 
Nasr, A. (1940a). A report of some marine algae collected from the vicinity of Alexandria. Fouad Institute of Hydrobiology and Fisheries. Notes et Memories. 36: 1-33.

Nasr, A. (1940b). A study of the occurrence of some marine algae on the Egyptian Mediterranean coast Ibid. 37: 1-9.

Nessim, R. and El-Deek, M. (1993). Eutrophication in Abu-Qir Bay, Proc. $3^{\text {rd }}$ Int. Conf. on "Environmental Protection is a must" HIPH of Alex. Univ. and USPD Alex. 13-15 April 1993 pp: 115-130.

Nisizawa, K., Noda, H., Ki Ku Chi, R. and Watanable, T. (1987). The main seaweed food in Japo. Proc. Inth Seaweed Symp. 12: 5-29.

Price, L.W. (1983). The radioactivity counting handbook. University of Cambridge.

Radwan. S. S. (1978). Coupling of two dimensional thin layer chromatography for the quantitative analysis of lipid Classes and their conistituents fatty acids. J. Chrom. Sci., 16: 538-542.

Savigny, J. and Audowin, V. (1809). Description d'Egypte. Hist. Nat. Text. 1:245-249.

Schlenk, H.; Mangold, H.; Gellerman, J.; Link, W.; Morrissette, R.; Holman, R. and Hayes, H. (1960). Comparative analytical studies of fatty acids of the alga Chlorella pyrenoidosa. J. Am. Oil Chemist. Soc., 37: 547-552.

Shafik, M.A. (1992). Urea-degrading enzyme in water hyacinth (Eichhornia crassipes. Mart). In national Symposium on water Hyacinth. Assuit University. 81-94.

Shafik, M.A. (1993). ${ }^{14} \mathrm{C}$-urea metabolism by some marine algae from Alexandria in combination with sewage treatment. Egypt J. App. Sci., 8(10): 275-303.

Silva, P.; Basson, P. and More, R. (1996). Catalogue of benthic marine algae of the Indian Ocean. University of California Publications in Botany. 79: 11259.

Stegenga, H.; Bolton, J. and Anderson, R. (1977). Seaweeds of the South African West Coast. pp. 2:1-655. Cape town. Boleus Herbarium, University of Cape town.

Svedilius, N. (1915). Zytologisch-Entwicklungsgeschichtliche studien uber Scinaia furcellata. Nov. Act. Reg. Soc. Sci. Upsaliensis. 4 (4): 1-55.

Syrett, P. P.; Flynn, J.; Molloy, C.; Dixor, G.;Peplinsha, A. and Cresswell, R. (1986). Effects of nitrogen deprivation on rates of uptake of nitrogenous compounds by the diatom Phaeodactylum tricormutum Bohlin. New Phytol., 102: 39-44. 
Syrett, P.J. and Leftely, J.W. (1976). Nitrate and urea assimilation in experimental biology. 11: 221-234.

Tempst, P. and Jozef, V. B. (1983). The complete amino acid sequence of the low-spin Class 11 cytochrome C-556 from Agrobacterium tumefaciens strain B2a. Eur. J.bichem., 129: 603-614.

Thomas, E. and Syrett, P. (1976). The assay of ATP: urea amidolyase in whole cells of Chlorella. New Phytol., 76: 409-414.

Tseng, C.K. (1941). Studies on the Chaetangiaceae of Chine. Bulletin of the Fan Memorial Institute of Biology, Botany. 11: 83-118.

Vroom, P. and Abbott, I. (2004). Scinaia huismanii sp. Nov. (Nemaliales, Rhodophyta): an addition to the exploration of the marine algae of the north western Hawaiian Islands. Phycologia. 43: 445-454.

Williams, S.K. and Hodson, R.C. (1977). Transport of urea at low concentration in Chlamydomonas reinhardii. J. Bact., 130: 266.

Wynne, M.J. (1989). Scinaia interrupta (A.D.C.). comb. Nov. an older name for S. turgida Chemin, and Scinaia pseudocripsa (Clemente) comb. Nov. an older name for Scinaia forcellata Biv. Bern. (Galaxuraceae, Rhodophyta) Candolleae. 44: 129-136.

Wynne, M.J. (2005). A check-list of benthic marine algae of the tropical and subtropical western Atlantic: second revision. Beihefte zur Nova Hedwigia. 129: 1- 152.

Yasuda, M. (1931). Determination of the iodine number of lipids. J. Biol. Chemist. 1: 401-409.

Yoshida, T. (1998). Marine algae of Japan. Uchida Rokakuho. Tokyo. 1222pp. (in Japanese). 


\title{
طحلب سينايا كومبلاناتا من البحر المتوسط بالإسكندرية ـ مصر
}

\section{ماجدة علي شفيق}

\author{
قسم العلوم البيولوجية والجيولوجيا- كلية التربية - جامعة الإسكندرية. ج.م.ع
}

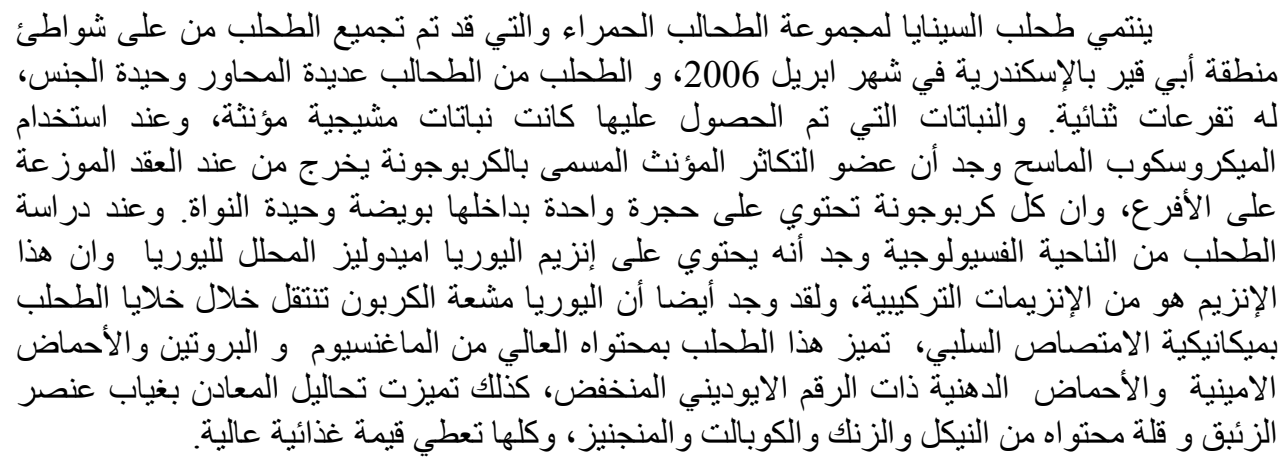

